\title{
Student Team Achievement Division (STAD) and Students' Attitude Towards Writing Achievement at SMP N 34 Pekanbaru
}

\author{
Nadia Nurul Huda ${ }^{1}$ \\ ${ }^{1}$ Universitas Negeri Padang, Padang, Indonesia, ه(email),nadyanh@ymail.com
}

\begin{abstract}
This research aimed at finding out (1) whether any significant difference of students' writing skill between those who were taught using student team skill division (STAD) and those who were taught using think pair share (TPS); (2) whether the students with a high attitude who were taught through STAD had better writing skill as compared to who were taught through TPS; (3) whether the students with a low attitude who were taught through STAD had better writing skill as compared to who were taught through TPS; (4) whether any interaction between techniques (STAD and Think Pair Share technique) and students' attitude on students' writing skill. This research was carried out at SMP N 34 Pekanbaru. The design of this research was quasi experimental research with $2 \times 2$ factorial designs. The samples of this research comprised 35 students of class VIII.2 as an experimental group and 35 students of class VIII 3 as a control group, which were selected using cluster random sampling technique. Hyphothesis 1, 2, and 3 were analyzed using Mann-Whitney U test, while the hyphotesis 4 was analyzed using two way anova. Hyphotesis 1 resulted p value $0.000<0.05$, which meant that there was a significant difference of students' writing skill between those who were taught using student team skill division (STAD) and those who were taught using think pair share (TPS). The hyphotesis 2 resulted $\mathrm{p}$ value $0.000<0.05$, which meant that the students with a high attitude who were taught through STAD had better writing skill as compared to who were taught through TPS. The hyphotesis 3 resulted $p$ value $0.006<$ 0.05 , which meant that the students with a low attitude who were taught through STAD had better writing skill as compared to who were taught through TPS. The hyphotesis 4 resulted $\mathrm{p}$ value $0.565>0.05$, which means that there was no any interaction between techniques (STAD and Think Pair Share technique) and students' attitude on students' writing skill.
\end{abstract}

Keywords: Student Team Skill Division (STAD), Think Pair Share (TPS), Attitude, Writing Skill

\section{INTRODUCTION}

Writing is one of the communicative skills which is needed by students. In writing, the students are able to communicate their thought through writing. This activity makes the language students learn writing. Through writing, the students are able to communicate their message in the large target of the audience. Furthermore, the students should be able to compose a correct structure, in order to make their text is understood by the reader. Moreover, the students have to understand the vocabulary, grammar, and structure of the text.

In Indonesia, Kemendikbud number 58 (2014) regulates the 2013 curriculum in which the students are compulsory to be able to write a short text. This requirement is regulated to control the curriculum structure of junior high school. In this regulation, the junior high school students are compulsory to be able to write short functional texts. The junior high school students are compulsory to have the ability to write some short functional text such as narrative, descriptive, recount, and procedure. Based on the 2013 curriculum, the procedure text is compulsory to learn by the second grade of junior high school in the context of recipe and manual.

Writing has some steps in order to produce good text. The complex steps of writing will be helpful for the beginner of writing students, in order to make their text in the correct structure. The beginning of the steps are to make sure the choice of vocabularies are appropriate, then the correct structure of grammar. According to Clark (2003) writing related to some process such as planning, drafting, revising and editing. If the students follow those steps, it helps the students to complete the writing activity and produce a text. Moreover, the success of this process can be affected by the strategy which is implemented by the teachers to make teaching and learning purposefully and enjoyable.

One of the strategies that can be used in order to make the writing activity purposefully and enjoyable either for students and teachers which is cooperative learning, namely Student Team Achievement Division (furthermore 
STAD). Slavin (1995) devised "STAD is a cooperative learning in which consist of four to five students with different ability, gender and ethnicity". STAD makes the teaching and learning process become intentional and pleasant for the students to learn in a group, including learning writing.

STAD is a cooperative learning that consists of some elements. According to Brown and Ciuffetelli (2009) cooperative learning requires students to work together in groups that increase learning. In the group, the students have responsibilities to make sure all the members of the group understand the topic. Moreover, Slavin adds that there are some elements in STAD, the elements are classroom presentation, teamwork, quizzes, individual improvement, and team recognition. Beside strategies, the success of learning are affected by some factors, such as the attitude of students toward the learning.

Students' attitude is additionally a vital factor in a learning process. Attitude give effect to the students in the way to reach the achievement in learning writing. According to Ibeh et al (2013), the varieties of methods in teaching raise students' attitude. It means that students' attitude can be affected based on the ways teachers taught the lesson. Any methods, strategies and/or approach in which implemented by the teachers are able to affect students' attitude in learning the materials. The result of the research of Ocampo (2015) presented that the students that have been exposed to STAD have more favorable attitude toward the materials. It is proved that strategies in teaching are able to influence students' attitude.

There are some researchers already implemented STAD in their research. One of the researchs done by Khansir (2015) entitles The Impact of Student team achievement division on Iranian EFL Learners' Listening Comprehension. This study gives support for the effectiveness of STAD while it used in teaching and learning. The result of the study shows that the interaction of students inside the team is naturally that help listening comprehension of Iranian EFL learner. Moreover, STAD allows the Iranian EFL learners to comprehend information and also associated the idea with their peers in a team.

Unlike the research above, this research is intended to implement the STAD for the 2nd-grade students of Junior High School. Moreover, this research is trying to find out the effect of STAD and students' attitude toward students' writing achievement in procedure text. While the teacher in the classroom is using other methods to teach the writing of procedure text. The aim of this research is to change the low attitude of the students in writing to become high by exposure the students with teamwork, in which make the students enjoy the learning process. If the students are able to enjoy the learning process, then it is expecting that the learning outcomes is increasing then before the students are exposed to the strategy.

It is assumed that STAD can be used in teaching and learning of English in Indonesia. Based on the result of research before, Iran and Indonesia have a common in English as a foreign language which is obligatory to be learnt. Beside, the curriculum in Indonesia regulates the students to learn English language. This research is experimental research in which try to find out the effectiveness of STAD to help students gain their writing achievement in procedure text. Unlike the previous research, this research is also trying to observe the students' attitude toward the writing of procedure text in which affected by the STAD. This research will be implementing at 2nd-grade students of SMP N 34 Pekanbaru.

\section{METHOD}

The design of this research was quasi experimental research with $2 \times 2$ factorial designs. The samples of this research comprised 35 students of class VIII.2 as an experimental group and 35 students of class VIII 3 as a control group, which were selected using cluster random sampling technique. The instrument used were attitide quesionnaire and writing test.

\section{RESULT AND DISCUSSION}

The result of the first hypothesis showed that the mean rank of the experimental class which was treated using STAD technique was higher than control class which was not taught using STAD technique. The mean rank of students' writing achievement in the experimental class was 45,29 and in the control class was 25,71. Furthermore, the $\mathrm{P}$ value indicated $0,000<0,05$. These data indicate students' writing achievement of procedure text in experimental class is higher than in the control class. Briefly, applying STAD technique had a significant impact on students' writing ability, especially writing a procedure text.

This research finding is in line with one conducted by Pratiwi (2016), who suggested that STAD technique could increase students' writing. Furthermore, Newman and Thompson (1987) claims that STAD is the most successful cooperative learning technique to improve students' achievement. In STAD approach, there are some steps that could easily be followed by students in order to create better writing production. The most important feature in STAD is teams. The students are devided into small group comprising of four-five individuals who have different levels of ability and different gender to work together to accomplish a shared learning goal. It means, STAD emphasizes on the use of team success. Members in the team should ensure all their teamates mastering the material. Otherwise, they will not be ablte to produce better writing. Thus, the steps in STAP could motivate the students to perform better. In STAD technique, the students will be more active and dominant than the teacher.

The technique made the students develop their critical thinking and consider the failure since they interact each other members, give them greater information and more negotiation of meaning by sharing the ideas. As Novitarini (2013) states that STAD technique can create interaction between students-students and students-teacher, 
and students work cooperatively. As a result, it helps the students to feel free to give or explore their ideas in making the text, so they have interest and willingness to write.

In addition, cooperative learning technique also gives a relaxed atmosphere so that the students will not feel burden to learn. The finding of this study indicated that the usage of STAD technique in teaching writing successfully improved students' writing skill. The finding of this research supported Hayatunisa's (2013) research finding who claimed that STAD is found to be helpful for students academically and socially. The technique is also proven to motivate the students to learn more so that they can improve their writing skill.

Another correspond finding was from Novitarini (2009) who affirmed that the result of the students' progress during the teaching learning process by using STAD was good. She also stated STAD was good to be applied in teaching writing descrptive text. Then, the finding was also in line with last finding research from Nursyifarani and Herawati (2013) who found the result in pretest was unsastisfying. However, after given treatments by using STAD, all students passed the standard score. It can be induced that STAD technique able to improve students' ability in writing procedure text. In brief, based on those explanations, it can be concluded that STAD technique could improve students' writing skill

The result of the second hypothesis indicated that the students with high attitude who were taught using STAD technique had higher score than students who did not apply the STAD technique. The mean rank of writing for students who both had high attitude and being taught using STAD technique was higher than those who were taught using Think Pair Share $(25,50>11,50)$. In addition, the $\mathrm{P}$ value indicated 0,000 , which is less than 0,05 . In brief, the students with high attitude who applied the STAD technique had higher writing achievement than those who did not apply the STAD technique.

In addition to the right technique that should be considered by English teachers in teaching writing, students' attitude in writing is another considerable factor than can influence their' writing production. On the other words, students' writing production will not be maximal if their attitude in writing is low although the technique used is already appropriate. Briefly, the students who have high attitude in writing and mediated by appropriate technique used by the teacher in the classroom definitely will be able to produce better writing than ones who are taught by the same technique but they have low atttitude. This statement is supported by a research finding conducted by (Hashemian \& Heidari, 2013).

They reveal that there's a relationship between positive attitude and writing ability. They propose that students ought to have positive attitude to writing because it can help them to attain way better writing achievement. In expansion, Graham et al., (2007) conducted a study on primary grade students to discover their attitude towards writing and their writing achievement. They found out that students who have more positive writing attitudes have way better writing achievement than other students who have less favorable writing attitudes.

The result of their study proposes that writing attitudes can foresee writing achievement. Additionally, Gupta \& Woldermariam (2011) uncover that students with strong motivation perform high level of satisfaction, confidence, perceived ability, and positive attitude toward writing, and use frequent writing methodologies. This implies that the better attitude the students are, the more writing methodologies they would use. However, the appropriate technique is considerable in teaching, especially teaching writing since creating a good writing in the native language is a hard work, let alone in the foreign language like English. Behind its creation, there should be a great effort and a winding process should be done by writers to make their writing becomes meaningfuI.

Consequently, the teachers should be able to select the correct technique in teaching writing. One of the good techiques than can be implemented by teachers in teaching writing is STAD. According to Cinelli(1994), Cooperative learning motivates the students to learn and energizes understudies to work together to maximize learning. Richard and Renandya (2002:49-50) also state that cooperative learning promote better learning because of some advantages such as it has a greater motivation for learning, a more relaxed atmosphere, more negotiate of meaning, and a greater amount of comprehensible input. One kind of cooperative learning is Student Team Achievement Division (STAD).

Furthermore, through STAD, the students can develop not only their writing achievement but also their attitude. The students can work together each other in creating a better procedure text since the students can share their ideas each other. This is in line with Raj (2012) who revealted that that STAD compared to direct instruction promoted high attitudes, showed better achievements and motivated students to learn.

The result of the third hypothesis presented that the mean rank of students with low attitude within the experimental group was, which is higher than ones in the control group $(22.18>12.82)$. The students with high attitude either in the experimental group or in the control group had higher writing achievement than those who had low attitude. The mean score of students' writing achievement whose attitude were high in the experimental group was 76.30, while the mean score of students' writing achievement whose attitude were low was 66.08.

Thus, the mean difference between the high and low students was 10.22. Furthermore, the mean score of students' writing achievement whose attitude were high in the control group was 68.15 , while the mean score of students' writing achievement whose attitude were low was 59.51. Thus, the mean difference between the high and low students was 8.64. In summary, in addition to teaching technique, students' attitude also had impact on students' writing achievement.

The examination of the fourth hypothesis appeared that there is not any interaction which occurred between 
both teaching techniques and students' attitude on students' writing achievment of procedure text. The finding shows that the $\mathrm{P}$ value for interaction indicated 0.564 , which is higher than 0.05. In other words, alternative hypothesis (Ha) is rejected and null hypothesis (H0) is approved. If the null hypothesis is accepted, there is an implication that there is no relation between attitude and students' writing achievement.

So, it can be said that STAD technique can be implemented in teaching writing, especially a procedure text, without considering the students' attitude. It also means that students' attitude is not one of the variables which can influence the result of students' writing achievement. This finding is in line with the finding of research which conducted by Syaftinentias (2017), who found that there is no interaction between both teaching technique and students' attitude.

Moreover, the figure 2 page 121 shows that there are two parallel ordinal lines. It means that there's no interaction between attitude and students' writing ability. On other words, no matter what the students' level of attitude, the students taught by STAD strategy got higher score than those who were taught by non STAD strategy. From explanations above, it means that there was no any interaction between both techniques and students' attitude on their writing skill

\section{CONCLUSION}

Based on the research findings, some conclusions can be withdrawn as follows.

1.The students taught by using STAD strategy had better writing achievement of procedure text compared to those that taught by using Think Share Pair technique at second grade students of SMP N 34 Pekanbaru.

2.The students with high attitude that taught through Student Team Achievement Division (STAD) had better writing achievement of procedure text compared to those that taught through Think Pair Share at the eighth students of SMP N 34 Pekanbaru.

3.Students with low attitude that taught through Student Team Achievement Division (STAD) had better writing achievement of procedure text compared to those that taught through Think Pair Share at the eighth students of SMP N 34 Pekanbaru;

4.There was no an interaction between techniques (STAD and Think Pair Share technique) and students' attitude on students' writing achievement of procedure text at the eighth students of SMP N 34 Pekanbaru.

\section{ACKNOWLEDGMENTS}

I would like to thank Professor Jufrizal and Dr. Kurnia Ningsih for their professional advises and encourangment in this thesis process. Also thank to my colleagues for helping in the writing process. Last but not least for people around who always support in this process. Finally, I have a extraordinary expectation that my study will be advantageous and valuable for the ones who examined it

\section{REFERENCES}

[1] Ababneh, S. 2016. Attitude of Jordanian Students Towards Learning English Idioms. International Journal of English Language Education, Vol.4, No.1

[2] Allport, G. W. 1967. Attitudes. Readings in attitude theory and measurement.

[3] M.Fishbein edt John Wiley \& Sons. Cited from Hanane Dernoun. 2015.

[4] Anima, Chakravery \& Kripa. K. 2000. Dynamic of Writing. English Teaching Forum. Vol. 38 No.3

[5] Arikunto, S. 2008. Prosedure Penelitian Suatu Pendekatan Praktek. Rineka Cipta.

[6] Azwar, S. 2003. Sikap manusia, Teori, dan Pengukurannya. Pustaka Pelajar.

[7] Bachman, L. F. 1990. Fundamental considerations in language testing.Oxford: OUP.

[8] Baker, Colin. 1992. Attitudes and Language. Multilingual Matters LTD.

[9] Bem, D. J. 1974. Predicting some of People some of Time: The Research for Cross Situational Consistencies in Behavior. Psychology Review.

[10] Brown, H Douglas. 1980. Principles and Practice of Language Learning and Teaching. NJ: Prentice Hall.

[11] Brown, H Douglas. 2000. Principles of Language Learning and teaching (4th eds). Pearson Education.

[12] Brown, H.D. 2007. Teaching by Principles: An Interactive Approach to Language Pedagogy. Longman (Second Edition).

[13] Brown, H., Ciuffetelli, D.C. 2009. Foundational methods: Understanding Teaching and Learning. Pearson Educationa.

[14]Clark, I.L. 2003. Concepts in Composition Laurence Erbaum Associates;Inc.

[15] Day, R. R., Bamford, J. 1998. Extensive Reading in the Second Language Classroom. Cambridge University Press.

[16] Delpech, E. 2008. Investigating the Structure of Procedural Text for Answering How - to Question. LREC.

[17]Djiwandono, S, M. 2008. Tes Bahasa; Pegangan Bagi Pengajaran Bahasa. Pt. Indeks

[18] Eagly, A.H. \& Chaiken, S. 1993. The psychology of attitudes. TX: Harcourt Brace Jovanovich.

[19]Edelstein, M., Pival. 1988. The Writing Commitment. Hartcourt Brouce Javanovich Publisher.

[20]Elydirim, S., Ashton, S. 2006. Creating High Attitudes towards English as a Foreign Language. English Teaching Forum, Vol.4, No.2.

[21] Fishbein, M. \& Ajzen, I. 1975. Beliefs, attitudes, intention, and behavior: An introduction to theory and research. Reading, MA: AddisonWesley. 
[22] Gay, L.R., Airasian, Peter. 2000. Educational Research: Competencies for Analysis and Application (Sixth Edition). Prentice Hall.

[23] Gay, L.R., Airasian, P. 2003. Educational Research: Coompetencies for Analysis and Application (Sevent Edition). Prentice Hall.

[24] Gay, L.R \& Airasian, P. 2009. Educational research: Competencies for Analysis and Aplication (Ninth Edition). Prentice Hall.

[25] Glomo-Narzoles, D.T. 2015. Student Team Achievement Division: Its Effect on the Academic Performance of EFL Learners. American Research Journal of English and Literature, Vol.1, No.4.

[26] Harris, David P. 1997. Testing English as a Second language. New York. MC. Grow-Hill Publishing Company Limited.

[27] Hyland, K. 2004. Genre and Second Language Writing. Ann Arbor, MI: University of Michigan Press.

[28] Jabbari, M. J., Golkar, Negar. 2014. The Relationship Between EFL Learners' Language Learning Attitudes and Language Learning Strategies. International journal of Linguistic, Vol.6, No.3

[29] Jacobs, G. M., Power, M. A., Loh, W. I. 2002. The Teacher's Sourcebook for CooperativeLearning: Practical Techniques, Basic Principles, and Frequently Asked Questions. Thousand Oaks, CA: Corwin Press.

[30] Karahan, F. 2007. Language Attitude of Turkish Students Towards the English Language and its Use in Turkish Context. Journal of Arts and Science No.7.

[31] Khansir, A. 2015. The Impact of Student Team Achievement Division on Iranian EFL Learners' Listening Comprehension. Theory and Practice in Language Studies, Vol.5 No.8

[32] Lie. A. 2007. Cooperative Learning. PT. Grasindo.

[33] McCafferty, S.G., Jacobs, G.M., DaSilva Iddings. 2006. Cooperative Learning and Second Language Teaching. Cambridge University Press.

[34] Nunan, David. 2003. Practical English Language Teaching. Singapore: McGraw Hill Company.

[35] O’Malley, J.M., Pierce, L.V. 1996. Authentic Assessment for English Language Learners: Practical Approaches for Teachers. Massachusetts: Addison Wesley Publishing Company.

[36] Raimes, A. 1983. Techniques in Teaching Writing. Oxford: O.V.P.

[37] Riduwan. 2012. Metode dan Teknik Menyusun Proposal Penelitian. Alfabeta.

[38] Rusman. 2005. Model-Model Pembelajaran Mengembangkan Profesionalisme Guru. PT. Raja Grafindo Persada.

[39] Slavin, Robert. 1991. Student Team Learning: A Practical Guide to Cooperative Learning. National Education Association of the United States.
[40] Slavin, Robert. 1995. Cooperative Learning: Theory, Research, and Practice. Massachusetts: Allyn and Bacon.

[41] Suaeni. 2015. Improving Students' Skill in Writing Procedure Text Through Picture Sequences. Universitas Islam Negri Syarif Hidayahtullah. Jakarta

[42] Sugiyono. 2013. Metode Penelitian Pedekatan Kualitatif, Kuantitatif, dan R\&D. Alfabeta.

[43] Travers, R.M.W. 1973. Second Hand Book of Research in Teaching. Randmc Nally Publishing Company.

[44] Yuliani, Marta. 2008. Detik-detik Ujian Nasional Bahasa Inggris SMA. Intan Pariwara. Jakarta. 